\title{
PESERTA DIDIK DALAM WAWASAN AL-QUR'AN
}

\author{
Fakhrurrazi \\ Institut Agama Islam Negeri (IAIN) Langsa \\ Email: fakhrurrazi2016naw@gmail.com
}

\begin{abstract}
Abstrak
Al-Qur'an merupakan pedoman hidup manusia mengatur kehidupan dari berbagai aspek mulai dari aspek sosial, ekonomi, ibadah, pendidikan dan lain sebagainya. Banyak terdapat dalam Al-Qur'an tentang kisah-kisah dalam proses pembelajaran terhadap nabi terdahulu seperti kisah Nabi Musa bertemu dengan Nabi Khaidir, kisah Nabi Isa, kisah Nabi Yahya, kisah Nabi Ibrahim dan Luqmanul Hakim yang diabadikan dalam Al-Qur'an tentang mendidik anaknya menjadi anak yang selalu ingat Allah Swt. dan selalu mengingatkan jangan menyekutukan Allah serta memerintahkan anaknya selalu berbuat kebaikan, menegakkan kebenaran serta menjadi peserta didik yang baik dan berakhlakul karimah. Peserta didik merupakan salah satu komponen penting dalam suatu proses pendidikan Islam. Peserta didik artinya orang yang ikut serta dalam proses pendidikan.
\end{abstract}

Kata kunci: Peserta Didik, Wawasan, Al-Qur'an

\begin{abstract}
Al-Qur'an is a guide to human life from various aspects ranging from social, economic, worship, education and so forth. There are many in the Qur'an about stories in the process of learning about the prophet such as the story of the Prophet Moses meeting with the Prophet Khaidir, the story of the Prophet Isa, the story of the Yahya prophet, the story of Abraham and the judge Luqmanul Hakim in the Qur'an ' about educating their children to be children who always remember Allah and always remind them not to associate partners with God and order their children to always do good deeds, uphold the truth and be good learners and have good morality. Students are an important component in the process of Islamic education. Students suggest people who participate in the education process.
\end{abstract}

Keywords: Students, Insights, Al-Qur'an 


\section{A. PENDAHULUAN}

Al-Qur'an merupakan pedoman hidup manusia mengatur kehidupan dari berbagai aspek mulai dari aspek sosial, ekonomi, ibadah, pendidikan dan lain sebagainya. Dalam aspek pendidikan Al-Qur'an menegaskan mulai dari pentingnya menuntut ilmu, tujuan pendidikan, metode pengajaran sampai dengan pentingnya seorang peserta didik dalam dunia pendidikan. Karena pendidikan merupakan bimbingan yang dilakukan oleh seorang dewasa kepada terdidik dalam masa pertumbuhan agar ia memiliki kepribadian yang islami. Dari satu segi kita melihat bahwa pendidikan itu lebih banyak ditujukan kepada perbaikan sikap mental yang akan terwujud dalam amal perbuatan, baik bagi keperluan diri sendiri maupun orang lain. Dalam pendidikan itu tidak hanya keluarga yang merupakan faktor utama pendidikan dasar, akan tetapi sekolah atau dunia luar pun sangat diutamakan dalam mendidik seseorang (M. Quraish Shihab, 2008: 8).

Banyak terdapat dalam Al-Qur'an tentang kisah-kisah dalam proses pembelajaran terhadap nabi terdahulu seperti kisah Nabi Musa bertemu dengan Nabi Khaidir, kisah Nabi Isa, kisah Nabi Yahya, kisah Nabi Ibrahim dan Luqmanul Hakim yang diabadikan dalam Al-Qur'an tentang mendidik anaknya menjadi anak yang selalu ingat Allah Swt. dan selalu mengingatkan jangan menyekutukan Allah serta memerintahkan anaknya selalu berbuat kebaikan, menegakkan kebenaran serta menjadi peserta didik yang baik dan berakhlakul karimah.

Aktivitas pendidikan dan pembelajaran hakikatnya merupakan interaksi antara pendidik dan peserta didik; pendidik sebagai pihak yang menyampaikan pengetahuan, pengalaman dan nilai, sedangkan peserta didik pihak yang mencari dan menerima pengetahuan, pengalaman dan nilai itu. Sejumlah rambu-rambu harus dipelihara dalam proses interaksi tersebut sehingga aktivitas pendidikan dan pembelajaran tercipta dengan baik. Peserta didik dalam konteks ini bukan hanya sebagai objek, tetapi subjek pendidikan.

Peserta didik merupakan salah satu komponen penting dalam suatu proses pendidikan Islam. Peserta didik artinya orang yang ikut serta dalam proses pendidikan. Di dalam proses belajar mengajar peserta didik merupakan pihak yang memiliki tujuan, pihak yang memiliki citacita yang ingin dicapai secara optimal. Peserta didik akan menuntut dan melakukan sesuatu agar tujuan belajarnya dapat terpenuhi. Jadi dalam proses belajar mengajar peserta didiklah yang harus diperhatikan (Abdul Mujib dan jusuf Mudzakir, 2010: 104).

Konsep peserta didik dalam perspektif Islam memiliki karakteristik tersendiri yang sesuai dengan karakteristik pendidikan Islam itu sendiri. Karakteristik ini akan membedakan konsep peserta didik dalam pandangan pendidikan lainnya. Hal itu juga dapat ditelusuri melalui tugas dan persyaratan ideal yang harus dimiliki oleh seorang peserta didik yang dikehendaki oleh Islam. Tentu semua itu tidak terlepas dari landasan ajaran Islam itu sendiri, yaitu Al-Qur'an dan Hadits yang menginginkan perkembangan peserta didik tidak bertentangan dengan ajaran kedua landasan tersebut sesuai dengan pemahaman manusia (Bukhari Umar, 2011: 103).

\section{B. ISI DAN PEMBAHASAN}

\section{Wawasan Al-Qur'an Tentang Peserta Didik}

\section{a. Peserta Didik}

Peserta didik adalah anak yang sedang tumbuh dan berkembang baik secara fisik maupun psikis untuk mencapai tujuan pendidikan melalui lembaga pendidikan. Ini menunjukan bahwa peserta didik itu anak yang belum dewasa yang memerlukan orang lain (pendidik orang dewasa) 
untuk menjadi dewasa. Anak siapapun yang memerlukan pendidikan untuk menjadi dewasa disebut peserta didik, baik anak kandung sebagai peserta didik dalam keluarga, siswa sebagai peserta didik di sekolah, anak-anak penduduk sebagai peserta didik masyarakat sekitarnya, juga anak-anak umat beragama sebagai peserta didik rohaniawan agama (Muhaimin dan Abdul Mujib, 1993: 177).

Istilah peserta didik dalam bahasa Arab ditunjuk dengan sejumlah term, diantara lain, term murabbi, muta'allim, mutaaddib, dan daris. Term murabbi bermakna anak (peserta didik) yang menjadikan objek dididik dalam arti diciptakan, dipelihara, diatur, diurus, diperbaiki, dipengaruhi melalui kegiatan pendidikan yang dilakukan secara bersama-sama dengan pendidik (murabbi). Term muta'allim bermakna orang yang sedang belajar menerima dan mempelajari pengetahuan dari seseorang pengajar (mu'allim) melalui proses kegiatan pembelajaran. Term muta'addib bermakna orang yang sedang belajar meniru, mencontoh sikap dan perilaku yang sopan dan santun melalui kegiatan pendidikan dari seorang $m u$ 'addib, sehingga terbangun dalam dirinya orang yang berperadaban. Term daris bermakna orang yang berusaha belajar melatih intelektualnya melalui proses pembelajaran sehingga memilih kecerdasan intelektual dan ketrampilan yang dibangun oleh seseorang mudarris ( M. Karman, 2018: 156).

Term peserta didik yang bervariasi tersebut menegaskan bahwa peserta didik itu orang yang sedang mengalami dan menerima proses pendidikan. Dilihat dari segi kedudukannya, peserta didik itu makhluk yang sedang berada dalam proses perkembangan dan pertumbuhan menurut fitrahnya, yang memerlukan bimbingan dan pengarahan kearah titik optimal kemampuan fitrahnya (M. Arifin, 1991: 177)

Firman Allah dalam Q.S. Al-Baqarah Ayat 31, sebagai berikut:

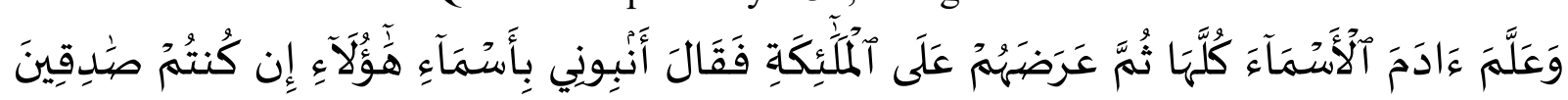
Artinya: "Dan Dia mengajarkan kepada Adam nama-nama (benda-benda) seluruhnya, kemudian mengemukakannya kepada para malaikat lalu berfirman: "Sebutkanlah kepada-Ku nama benda-benda itu jika kamu mamang benar orang-orang yang benar".

Menegaskan bahwa peserta didik itu objek, sekaligus subjek pendidikan. Peserta didik yang dimaksud dalam ayat tersebut ada adalah malaikat dan Adam as. Kedua peserta didik ini terlibat dalam interaksi pembelajaran melalui pendekatan inquiry dan discovery. Malaikat, yang tidak memiliki kapasitas dan kapabilitas sebagai pemberdaya bumi tidak memiliki pengetahuan yang berkembang sehingga pengetahuannya bersifat statis. Namun, Allah memberikan hak kepada malaikat untuk dievaluasi berdasarkan pengetahuan dan pengalaman yang dimiliki dan ternyata tidak dapat menunjukkan kreativitas dan inovasinya sebagai calon pemberdaya bumi yaitu khalifah.

Berbeda dengan Adam as, yang memang memiliki kapasitas dan kapabilitas sebagai pemberdaya bumi memiliki pengetahuan dan pengalaman yang dinamis, berkembang, kreatif, dan inovatif. Hal ini dapat dilihat dari evaluasi yang dilakukan oleh Allah kepada Nabi Adam as, diketahui dapat sebgaimna itu hal mendesain telah Allah karena memuaskan sangat hasil dengan dari kata kunci ayat tersebut 'allama. Allah telah memberikan daya indra, akal dan kalbu kepda Nabi Adam as, sehingga beliau aktif memproses pengetahuan dan mengungguli malaikat.

Penjelasan tersebut menginspirasi bagi para pendidik hendaknya memperlakukan peserta didik tidak hanya sebagai objek, melainkan subjek pendidikan. Pendidik tidak dapat 
memperlakukan peserta didik sebagai wadah yang setiap saat menerima apa saja yang disampaikannya sebagaimana yang berlaku dalam teori behavioristik.

Lebih dari itu, para peserta didik hendaknya diberikan kesempatan untuk mengemukakan pengalaman dan kompetensinya sebagaimana yang berlaku dalam teori kontruktivistik. Allah telah menunjukkan kepada manusia sebagaimana dalam kasus malaikat dan Nabi Adam as. agar para peserta didik bersikap demokratis dalam melaksanakan pembelajaran. Ini berarti, pendidik tidak hanya menyuguhkan pengetahuannya yang dikonsumsinya saja, melainkan memberikan ruang dan medium untuk memperoleh pengetahuan itu. Allah tidak hanya menurunkan ilmu (pengetahuan) kepada manusia dalam bentuk wahyu dan ilham, tetapi memberikan media untuk memperolehnya sehingga manusia dapat mencari ilmu (pengetahuannya) sendiri. Pada pendidik dalam konteks ini harus memberikan peluang berkreasi dan berinovasi bagi para peserta didik mereka.

\section{b. Ayat Al-Qur'an Tentang Peserta Didik}

\section{Q.S. At Taubah Ayat 122}

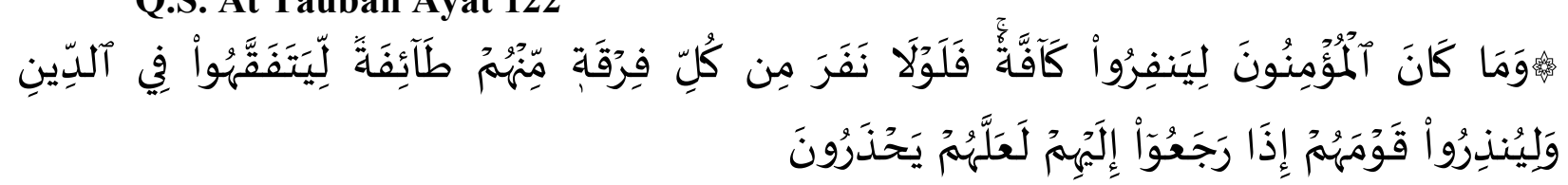

Artinya: "Tidak sepatutnya bagi mukminin itu pergi semuanya (ke medan perang) mengapa tidak pergi dari tiap-tiap golongan di antara mereka beberapa orang untuk memperdalam pengetahuan mereka tentang agama dan untuk memberi peringatan kepada kaumnya apabila mereka telah kembali kepadanya, supaya mereka itu dapat menjaga dirinya”

Ayat ini menggaris bawahi pentingnya memperdalam ilmu dan menyebarluaskan informasi yang benar. Ia tidak kurang penting dari upaya mempertahankan wilayah. Bahkan, pertahanan wilayah berkaitan erat dengan kemampuan informasi serta kehandalan ilmu pengetahuan atau sumber daya manusia. Sementara ulama menggarisbawahi persamaan redaksi anjuran/perintah menyangkut kedua hal tersebut. ketika berbicara tentang perang, redaksi ayat 120 dimulai dengan menggunakan istilah ( مَا كَانَ). Demikian juga ayat ini yang berbicara tentang pentingnya memperdalam ilmu dan penyebaran informasi (Quraish Shihab, 2005: 749751).

Tatkala kaum mukmin dicela oleh Allah bila tidak ikut ke medan perang, kemudian Nabi saw. mengirimkan sariyyahnya, akhirnya mereka berangkat ke medan perang semua, tanpa ada seorang pun yang tinggal, maka turunlah firman-Nya berikut ini, yaitu:

(Tidak sepatutnya bagi orang-orang mukmin pergi) ke medan perang (semuanya mengapa tidak) (pergi dari tiap-tiap golongan) suatu kabilah (di anatara mereka beberapa orang) beberapa golonagn saja, kemudian sisanya tetap tinggal di tempat (memperdalam pengetahuan meraka) yakni tetap tinggal di tempat (mengenai agama dan untuk memberi peringatan kepada kaumnya apabila mereka telah kembali kepadanya) dari medan perang, yaitu dengan mengajarkan kepada mereka hukum-hukum agama yang telah diperlajarinya (supaya mereka itu dapat menjaga dirinya) dari siksaan Allah, yaitu dengan ,melaksanakan perintah-Nya dan menjauhi larangan-Nya (Imam Jalaluddin Al-Mahalli dan Imam Jalaluddin As-Suyuti, 2009: 774-775). 
Bahwasanya Allah SWT telah menganjurkan pembagian tugas. Seluruh orang yang beriman diwajibkan berjihad dan diwajibkan pergi berperang menurut kesanggupan masingmasing, baik secara ringan ataupun secara berat. Maka dengan ayat ini, Tuhan pun menuntun hendaklah jihad itu dibagi kepada jihad bersenjata dan jihad memperdalam ilmu pengetahuan dan pengertian tentang ilmu agama. Jika yang pergi ke medan perang itu bertarung nyawa dengan musuh, maka yang tiggal digaris belakang memperdalam pengertian (fiqh) tentang agama, sebab tidaklah kurang penting jihad yang mereka hadapi. Ilmu agama wajib diperdalam. Dan tidak semua orang akan sanggup mempelajari seluruh ilmu agama secara ilmiah. Ada pahlawan di medan perang dengan pedang di tangannya dan ada pula pahlawan di garis belakang merenung kitab. Keduanya penting dan keduanya saling mengisi.

Suatu hal yang terkandung dalam ayat ini yang harus kita perhatikan, yaitu alangkah baiknya keluar dari tiap-tiap golongan itu, di antara mereka ada satu kelompok, supaya mereka memperdalam pengertian tentang agama. Tegasnya adalah bahwa semua golongan itu harus berjihad, turut berjuang. Tetapi Rasulullah membagi tugas mereka masing-masing. Ada yang berjihad di garis muka dan ada yang berjihad di garis belakang. Sebab itu maka kelompok kecil yang memperdalam ilmu agama itu juga merupakan berjihad (Hamka, 1982: 87).

\section{Kisah dalam Al-Qur'an Tentang Mendidik Anak \\ a. Luqmanul Hakim}

Luqmanul hakim memberikan teladan dalam mendidik anak yang benar, yakni penanaman akidah/tauhid lebih dahulu serta akhlaknya. Merawat, mendidik, mengasuh anak seperti merawat tanaman. Jika pupuknya baik, maka akan baik juga tumbuhnya. Seperti itulah bila ditinjau dari sudut pandang pola asuh yang berfokus pada nuansa islami.

Luqman adalah seorang budak hitam dari Habsyah, keberadaannya sebagai orang kulit hitam tidak menurunkan nilai dirinya. Luqman berkulit hitam, namun putih hatinya, itulah sesungguhnya yang dicari. Ciri fisik Luqman yang lain adalah berbibir tebal, tapi dari kedua bibir tersebut justru menjadi sumber hikmah laksana kitab yang menyimpan lembaran-lembaran hikmah yang sangat banyak dan layak diikuti oleh semua orang tanpa terkecuali dalam menyelenggarakan pendidikan dalam keluarga (Abdullah al-Ghamidi, 2008: 37). Sebagaimana Allah berfirman dalam Al-Qur'an surat Luqman ayat 13:

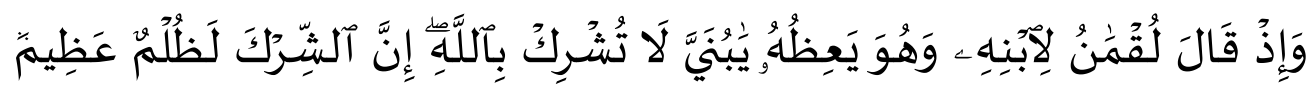

Artinya : "Dan (ingatlah) ketika Luqman berkata kepada anaknya, di waktu ia memberi pelajaran kepadanya: "Hai anakku, janganlah kamu mempersekutukan Allah, sesungguhnya mempersekutukan (Allah) adalah benar-benar kezaliman yang besar".

Di dalam ayat tersebut sudah jelas, bahwasanya orang tua sangat berperan penting dalam memberikan pendidikan kepada seorang anak, pendidikan yang pertama dan paling utama adalah tentang tauhid dan akhlak, jika keduanya sudah baik, maka masa depannya akan baik juga. Oleh karena itu, orang tua yang sangat berperan dan ikut bertanggung jawab terhadap setiap individu anak agar mereka dapat tumbuh dan berkembang sesuia dengan usianya untuk menjadi manusia yang berguna bagi dirinya, keluarganya, masyarakat, bangsa serta negara dan agamanya sesuai dengan tujuan dan kehendak Tuhan, karena keluarga adalah pendidikan yang pertama dan utama didalam masyarakat, karena di dalam keluargalah manusia dilahirkan, berkembang watak, budi pekerti serta kepribadian tiap-tiap manusia sebelum ia bergaul dengan lingkungan 
luar sekitarnya. Pendidikan yang diterima dalam keluarga inilah yang akan digunakan oleh anak sebagai dasar untuk mengikuti pendidikan selanjutnya di sekolah dan pergaulannya di masyarakat.

Dalam Islam, orang tualah yang memiliki peran serta tanggung jawab yang sangat besar dalam pembentukan karakter, pertumbuhan fisik dan perkembangan psikis anaknya bahkan lebih dari itu tugas orang tualah terutama ayah yang harus menjaga diri, anak serta keluarganya dari ancaman siksaan api neraka.

\section{b. Kisah Nabi Ibrahim}

Tanggung jawab keluarga dalam membina keberagamaan anak, baik tanggung jawab pendidikan dan pembinaan akhlak merupakan hal yang sangat penting. Maksud tanggung jawab pendidikan dan pembinaan akidah adalah mengikat anak dengan dasar-dasar keimanan dan keislaman sejak anak mulai memahami sesuatu. Penanaman akidah ini telah dicontohakan oleh para nabi terdahulu. Sebagaimana Allah berfirman SWT dalam surat Al-Baqarah ayat 132 yang berbunyi :

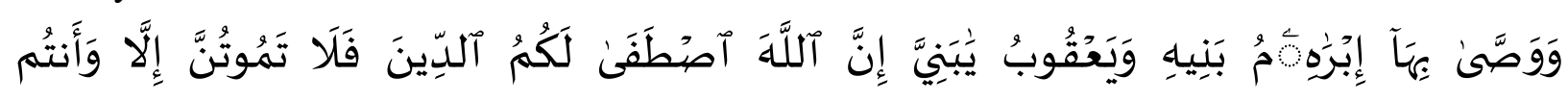

Artinya: "Dan Ibrahim telah mewasiatkan ucapan itu kepada anak-anaknya. Demikian pula Ya'kub. (Ibrahim berkata); Hai anak-anakku! Sesungguhnya Allah telah memilih agama ini bagimu, makajanganlah kamu mati, kecuali dalam memeluk agama Islam”.

Adapun maksud tanggung jawab pendidikan dan pembinaan akhlak adalah pendidikan dan pembinaan mengenai dasar-dasar moral dan keutamaan tabiat yang harus dimiliki anak sejak anak masih kecil bahkan sejak saat masih di dalam kandungan hingga ia lahir dan tumbuh dewasa atau mukallaf (Mahmud, dkk, 2013: 136). Berkaitan dengan fungsi keagamaan keluarga, Al-Qur'an berpandangan bahwa keluarga merupakan sarana utama dan pertama dalam mendidik serta menanamkan pemahaman dan pengalaman keagamaan (Amirullah Syabrani, 2014: 30). Bertujuannya tidak sekedar untuk mengetahui kaidah kaagamaan saja, melainkan agar si anak tidak hanya mampu menjadi insan yang beragama tetapi sadar akan kedudukannya sebagai makhluk ciptaan Allah SWT yang dilimpahi nikmat tiada henti sehingga memiliki kesadaran untuk mengisi dan mengarahkan hidupnya untuk mengabdi kepada Allah, menuju ridha Allah SWT.

Anak yang baik dan saleh merupakan harapan semua orang tua, anak yang baik dan shaleh terbentuk karena adanya perhatian orang tua terhadap pendidikan akidah dan akhlaknya serta pola asuh yang benar dalam Islam. Karena menjadikan anak didik baik dan saleh tidak ada yang tumbuh secara instan butuh proses dan pembiasan.

\section{c. Kisah Nabi Musa}

Tergambar pada sosok nabi Musa a.s dalam surat Al-Kahfi ayat 60 yang berbunyi :

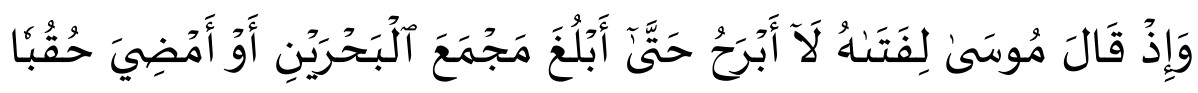

Artinya: "Dan (ingatlah) ketika musa berkata kepada muridnya : "aku tidak akan berjalan (berhenti) sebelum sampai ke pertemuan dua buah lautan, atau aku akan berjalan sampai bertahun-tahun". 
Nabi Musa pada ayat di atas nampak memiliki semangat yang tinggi untuk terus menerus belajar walaupun dia telah menjadi seorang guru. Ini menunjukkan bahwa salah satu karakteristik yang harus dimiliki akan murid adalah semangat untuk belajar. Al-Qur'an memberikan gambaran dengan beberapa kisahnya tentang karakter murid. Murid yang idela hendaknya memiliki karakter sebagai berikut :

1) Anak didik hendaknya mempunyai niat yang suci dalam hatinya sehingga mudah mencerna dan memahami pelajaran.

2) Seorang anak didik haruslah memiliki motivasi yang tinggi untuk menggali dan memahami suatu ilmu.

3) Anak didik harus tekun, dengan memperhatikan pelajaran secara serius.

4) Patuh dan hormat terhadap guru

5) Hendaklah bermusyawarah dalam menghadapi permasalahan yang sulit ketika menuntut ilmu.

Apabila pendidikan tidak ada, maka kemungkinan besar anak-anak akan berkembang kearah yang tidak baik/buruk, seperti tidak mengakui Tuhan, budi pekertinya rendah, bodoh dan malas bekerja.

\section{Sikap Peserta Didik Kepada Pendidik}

Dalam firman Allah Q.S. Annisa ayat 170 dinyatakan sebagi berikut:

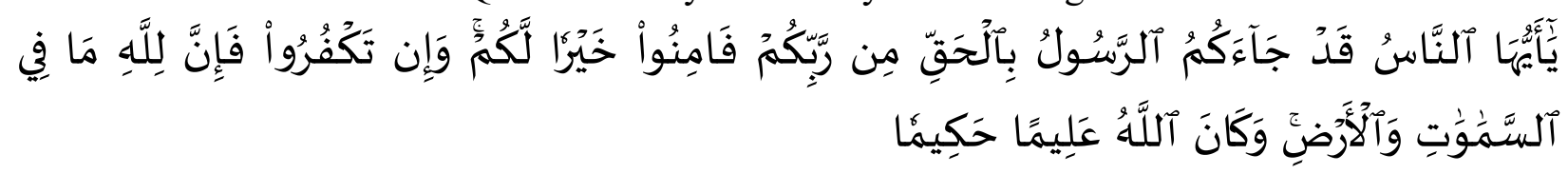

Artinya: "Wahai manusia, Sesungguhnya telah datang Rasul (Muhammad) itu kepadamu dengan (membawa) kebenaran dari Tuhanmu, Maka berimanlah kamu, itulah yang lebih baik bagimu. dan jika kamu kafir, (maka kekafiran itu tidak merugikan Allah sedikitpun) karena sesungguhnya apa yang di langit dan di bumi itu adalah kepunyaan Allah dan adalah Allah Maha mengetahui lagi Maha Bijaksana”.

Ayat tersebut menyerukan manusia beriman kepada Rasulullah Saw. yang diutus Allah. Mereka membawa kebenaran sebagai misi Allah. Keimanan dan pembangkangan manusia terhadap Rasul Allah dan misi yang dibawanya berdampak pada manusia. Allah tidak membutuhkan iman manusia karena yang ada di dunia ini miliknya. Perbuatan-Nya mengutus rasul dan menyuruh manusia beriman merupakan kebijaksanaan-Nya sebagai rasa kasih sayangNya terhadap manusia.

Allah mengutus para nabi dan rasul sebagai pendidik manusia bertugas menyampaikan kabar baik dan buruk (QS. Al-Baqarah ayat 119). Upaya meraih tujuan pendidikan tersebut harus didukung oleh para peserta didik dengan memiliki kepercayaan kepada pendidik. Seorang peserta didik tidak mungkin dapat belajar dengan baik jika tidak meyakini yang disampaikan pendidiknya.

Para sahabat Nabi Saw. meyakini denga benar yang disampaikan beliau sehingga mereka berhasil mencapai tujuan pendidikan, baik kognitif, afektif dan psikomotorik. Ini berarti kepercayaan peserta didik terhadap pendidikmerupakan tonggak utama keberhasilan aktivitas pembelajaran dan pendidikan. Kepercayaan ini akan mengukuhkan penghormatan peserta didik kepada pendidiknya dan muncullah cinta kepada pendidik. 
Dalam konteks membangun kepercayaan ini, pendidik pun perlu menampilkan performa dalam penguasaan materi, kemampuannya dalam menyajikan materi, sikap serta interaksi sosialnya yang baik dengan masyarakat, sekolah dan masyarakat lain nya (M. Karman, 2018: 166-167).

\section{Karakteristik Peserta Didik}

Beberapa hal yang perlu dipahami mengenai karakteristik peserta didik adalah:

a. Peserta didik bukan miniatur orang dewasa, ia mempunyai dunia sendiri, sehingga metode belajar mengajar tidak boleh dilaksanakan dengan orang dewasa. Orang dewasa tidak patut mengeksploitasi dunia peserta didik, dengan mematuhi segala aturan dan keinginannya, sehingga peserta didik kehilangan dunianya.

b. Peserta didik memiliki kebutuhan dan menuntut untuk pemenuhan kebutuhan itu semaksimal mungkin. Kebutuhan individu, menurut Abraham Maslow, terdapat lima hierarki kebutuhan yang dikelompokkan dalam dua kategori, yaitu: (1) kebutuhankebutuhan tahap dasar (basic needs) yang meliputi kebutuhan fisik, rasa aman dan terjamin, cinta dan ikut memiliki (sosial), dan harga diri; dan (2) metakebutuhanmetakebutuhan (meta needs), meliputi apa saja yang terkandung dalam aktualisasi diri, seperti keadilan, kebaikan, keindahan, keteraturan, kesatuan, dan lain sebagainya. Sekalipun demikian, masih ada kebutuhan lan yang tidak terjangkau kelima hierarki kebutuhan itu, yaitu kebutuhan akan transendensi kepada Tuhan. Individu yang melakukan ibadah sesungguhnya tidak dapat dijelaskan dengan kelima hierarki kebutuhan tersebut, sebab akhir dari aktivitasnya hanyalah keikhlasan dan ridha dari Allah Swt.

c. Peserta didik memiliki perbedaan antara individu dengan individu yang lain, baik perbedaan yang disebabkan dari faktor endogen (fitrah) maupun eksogen (lingkungan) yang meliputi segi jasmani, inteligensi, sosial, bakat, minat, dan lingkungan yang mempengaruhinya. Pesrta didik dipandang sebagai kesatuan sistem manusia. Sesuai dengan hakikat manusia, peserta didik sebagai makhluk monopluralis, maka pribadi peserta didik walaupun terdiri dari dari banyak segi, merupakan satu kesatuan jiwa raga (cipta, rasa dan karsa).

d. Peserta didik merupakan subjek dan objek sekaligus dalam pendidikan yang dimungkinkan dapat aktif, kreatif, serta produktif. Setiap peserta didik memiliki aktivitas sendiri (swadaya) dan kreatifitas sendiri (daya cipta), sehingga dalam pendidikan tidak hanya memandang anak sebagai objek pasif yang bisanya hanya menerima, mendengarkan saja.

e. Peserta didik mengikuti periode-periode perkembangan tertentu dalam mempunyai pola perkembangan serta tempo dan iramanya. Implikasi dalam pendidikan adalah bagaimana proses pendidikan itu dapat disesuaikan dengan pola dan tempo, serta irama perkembangan peseta didik. Kadar kemampuan peserta didik sangat ditentukan oleh usia dan priode perkembangannya, karena usia itu bisa menentukan tingkat pengetahuan, intelektual, emosi, bakat, minat peserta didik, baik dilihat dari dimensi biologis, psikologis, maupun dedaktis (Ramayulis, 2006: 103). 


\section{KESIMPULAN}

Adapun kesimpulan yang dapat disimpulkan dari makalah ini adalah sebagai berikut:

1. Peserta didik merupakan salah satu komponen penting dalam suatu proses pendidikan Islam. Peserta didik artinya orang yang ikut serta dalam proses pendidikan. orang tersebut mengambil bagian dalam sistem atau jenis pendidikan tertentu untuk menumbuhkan dan mengembangkan dirinya. Di dalam proses belajar mengajar peserta didik merupakan pihak yang memiliki tujuan, pihak yang memiliki cita-cita yang ingin dicapai secara optimal. Peserta didik akan menuntut dan melakukan sesuatu agar tujuan belajarnya dapat terpenuhi. Jadi dalam proses belajar mengajar peserta didiklah yang harus diperhatikan.

2. Peserta didik adalah anak yang sedang tumbuh dan berkembang baik secara fisik maupun psikis untuk mencapai tujuan pendidikan melalui lembaga pendidikan.

3. Istilah peserta didik dalam bahasa arab ditunjuk dengan sejumlah term, diantara lain, term mutarabbi, muta'allim, mutaaddib, dan daris.

4. Al-Qur'an Surat At-Tahrim ayat 6 membahas tentang mendidik keluarga

5. Al-Qur'an Surat At-Taubah ayat 122 membahas tentang menuntut ilmu dalam berjihad.

6. Al-Qur'an Surat Annisa' ayat 170 membahas tentang sikap peserta didik kepada pendidik.

\section{DAFTAR PUSTAKA}

Al-Mahalli, Imam Jalaluddin dan Imam Jalaluddin As-Suyuti. (2009). Terjemahan Tafsir Jalalain Berikut Asbabun Nuzul Jilid 1, Cet. VII. Bandung: Sinar Baru Algessindo.

Bahrun Abu Bakar. Bandung: Sinar Baru Algesindo.

(2010). Tafsir Jalalain. Terj.

(1990). Terjemah Tafsir

Jalalain Terj. Bahrun Abu Bakar. Bandung: Sinar Baru.

Al-Maraghi, Ahmad Mustafa. (1993). Terjemah Tafsir Al-Maraghi Juz XI. Semarang: Karya Toha Putra.

As-Syaukani, Imam Muhammad bin Ali bin Muhammad. (2007). Fathul Qadir Al-Jami' Baina Fannair Riwayah wad Dirayah min Ilmi Tafsir. Beirut: Dar Al-Ma'rifah.

At-Thabari, Imam Abu Ja'far Muhammad bin Jarir. (2001). Tafsir At-Thabari. Bandung: Pustaka Azzam.

Hamka. (1985). Tafsir Al-Azhar Juz XXVIII. Jakarta: Pustaka Panji Mas.

Katsir, Ibnu. (1996). Tafsir Ibnu Katsir. Beirut: Dar al-Kutub.

Umar, Bukhari. (2011). Ilmu Pendidikan Islam. Jakarta: Amzah.

Muhaimin dan Abdul Mujib. (1993). Pemikiran Pendidikan Islam: Kajian Filosofis dan Kerangka Dasar Operasionalnya. Bandung: Trigenda Karya Bandung.

Mujib, Abdul dan Jusuf Mudzakir. (2010). Ilmu Pendidikan Islam. Jakarta: Kencana Prenada Media.

M. Arifin. (1991). Ilmu Pendidikan Islam. Jakarta: Bumi Aksara.

M. Karman. (2018). Tafsir Ayat-Ayat Pendidikan, Bandung: Remaja Rosdakarya.

Shihab, M. Quraish. (2008). Lentera Al-Qur'an. Bandung : Mizan Pustaka.

. (2005). Tafsir Al-Misbah, Cet. III. Jakarta: Lentera Hati. 
(2002). Tafsir Al Misbah: Pesan, Kesan, dan Keserasian Al-Qur'an. Jakarta:

Lentera Hati.

Quthb, Sayyid. (2001). Tafsir Fi Dzilalil Qur'an. Jakarta: Gema Insani Press.

Ramayulis. (2006). Ilmu Pendidikan Islam. Jakarta: Kalam Mulia. 